\title{
the 19th-century Tlingit potlatch: a new perspective
}

SERGEI KAN-University of Michigan

introduction

A number of Northwest Coast rituals labeled "potlatches" have been the subject of anthropological analysis.' Functionalist, ecological, psychological, structuralist, and other theories have been applied to this phenomenon since the time of Boas (Benedict 1934; Barnett 1938; Codere 1950; Suttles 1960; Piddocke 1965; Drucker and Heizer 1967; Rosman and Rubel 1971; Adams 1973; and so on). Only recently has it been subjected to symbolic analysis, which has generated interesting new interpretations but has led to the neglect of the sociology of the ritual (Snyder 1975; Goldman 1975; Walens 1981; Seguin 1984, 1985). The Tlingit potlatch has, by and large, escaped the attention of anthropologists concerned with interpretive theory.

The major ethnographers of Tlingit culture have emphasized the significant role played by the dead in the potlatch and the native view of the ritual as a memorial (Veniaminov 1886; Swanton 1908; Emmons 1920-45; McClellan 1954; Olson 1967; de Laguna 1972). By incorporating this native model of the potlatch and by drawing on previous accounts as well as data collected during fieldwork in 1979-80 and 1984 (including active participation in several potlatches), I have tried to produce a more holistic analysis of this ritual as it existed in the period between 1830 and 1890, which predated massive Christianization and other significant sociocultural changes.

I begin with a review of the major interpretations of the potlatch, including its Tlingit version, as well as a discussion of the 19th-century Tlingit funeral, the first stage in the cycle of mortuary rituals that culminated in the memorial potlatch. By focusing on the native characterization of the ritual as the "finishing of the dead body," I show that it resembles other rites of secondary treatment of the dead analyzed by Hertz (1960). Models of the mortuary ritual developed by Van Gennep (1960), Hertz (1960), Huntington and Metcalf (1979), and others are applied to the potlatch; the transformation of the deceased, the mourners, and their affines is also discussed. Finally, the symbolism of the various forms of ritual discourse and exchange is examined to broaden our understanding of the relationships among the four categories of potlatch participants: the hosts, the guests, and the deceased matrikin of each. I conclude the paper with

The paper explores the meaning of the 19th-century Tlingit memorial potlatch and explains some of the reasons for its centrality in the Tlingit sociocultural order. By drawing on existing accounts of this complex ritual and on data obtained during fieldwork in 1979-80 and 1984, the study focuses on the symbolism of ceremonial objects, ritual acts and discourse, as well as the interaction and relationships among actors. By treating the dead as active participants and by analyzing the role of the cultural values associated with them, the paper presents a more holistic interpretation of this ritual than previous works on the subject and suggests some implications of its findings for research on comparable ceremonies in other Northwest Coast societies. Imortuary ritual, symbolic analysis, potlatch, Northwest Coast, Tlingit] 
suggestions about the possible use of some of the methods and findings of this study in analyzing potlatches in other Northwest Coast societies.

\section{views of the potlatch}

The Northwest Coast potlatch, particularly its Southern Kwakiutl version, has been a favorite subject of debate in North American anthropology. Without trying to review all of the works on this topic, I will briefly discuss some of the major theoretical approaches, so as to put my own analysis in a proper perspective.

While Boas did not express his own view of the potlatch in any detail (Goldman 1975: viixi, 1-14), anthropologists of the Boasian tradition such as Barnett (1938), Garfield (1939), Codere (1950), and Drucker and Heizer (1967) have agreed that this ritual was

an ostentatious and dramatic distribution of property by the holder of a fixed, ranked and named social position, to other position holders. The purpose is to validate the hereditary claim to the position and to live up to it by maintaining its relative glory and rank against the rivalrous claims of the others ICodere 1950:63].

These scholars identified the crucial role of the potlatch in the sociocultural order "as a formal procedure for social integration, its prime purpose being to identify publicly the membership of the group and to define the social status of the membership" (Drucker and Heizer 1967:8). Such definitions could be applied to most Northwest Coast potlatches, including those of the Tlingit, although they leave out a number of significant aspects of the rites.

In the 1960s, cultural ecologists such as Suttles (1960) and Piddocke (1965) offered an alternative interpretation of the potlatch as a "device for leveling off inequities in natural resources among the neighbouring tribes and kinship groups" (Drucker and Heizer 1967:147). Since this model has already been criticized (Drucker and Heizer 1967; Snyder 1975; Seguin 1985), I will comment only on its inapplicability to the Tlingit case. To begin with, many potlatch gifts had no utilitarian value and "were not given according to recipients' needs, but to hosts' needs for prestige which could be enhanced by distributing luxury goods in large quantities" (Snyder 1975:151). Among the Tlingit, fishing grounds and other subsistence-related areas were owned by matrilineal groups, but nonmembers could usually obtain permission to enter them and use their resources by simply invoking their kinship ties with the owners (Olson 1967:56; Kan 1979-84). It was particularly shameful to deny access to one's affines, precisely the people who were the main guests at one's potlatch. Much of the trade took place between trading partners, who were often members of the same moiety, and who thus could never be the guests at each other's potlatches (de Laguna 1972:355; Kan 1979-84). Finally, it is not clear why the Tlingit (or other Northwest Coast peoples) would need such an elaborate and costly ritual to redistribute resources if they could usually obtain them by quicker and simpler means (cf. Seguin 1985:59). ${ }^{2}$

Another influential model of the potlatch, inspired by Lévi-Strauss, was developed by Rosman and Rubel $(1971,1972)$. In their analysis of six Northwest Coast societies, including the Tlingit, Rosman and Rubel argued that the potlatch was generated by social structure, and specifically by marriage rules that differentiated one society from another. Although a novel approach, the authors' inflexible application of Lévi-Strauss's ideas led to a misinterpretation of ethnographic data, noted by several scholars who had done fieldwork in the region (Adams and Kasakoff 1973; Vaughan 1975, 1985; Seguin 1985).

As far as the Tlingit case is concerned, this model seriously distorts the marriage system.' There is no evidence to support the authors' argument about the existence of a tripartite marriage structure linking one clan to two others. According to all sources (Oberg 1973; de Laguna 1972; Kan 1979-84), the ideal marriage rule (adhered to primarily by the aristocracy) linked two clans of the two moieties to each other. ${ }^{4}$ An erroneous interpretation of the Tlingit marriage 
system led Rosman and Rubel to view the Tlingit potlatch as a form of ritual exchange between the clan of the hosts and two clans of the opposite moiety acting as guests. ${ }^{5}$

While focusing on several important dimensions of the potlatch, the "Boasians," the cultural ecologists, and the structuralists ignored what might be called its "religious" or "symbolic" aspect. In the last decade the latter has become the focus of research. One of the originators of this approach, Mauss (1967), 60 years ago characterized the potlatch as a "total social phenomenon," which was simultaneously "religious," "mythological, "economic," "jural," and so forth.

Snyder's analysis of the Skagit potlatch (1975), which focused on the symbolism of food, and native ideas about purity and pollution, was followed by Goldman's (1975) and Walens' (1981) interpretations of Kwakiutl cosmology and religion. Although not the major focus of their work, they place the Kwakiutl potlatch in symbolic context and discuss it primarily as a religious phenomenon. Goldman's detailed and ethnographically grounded study attempts to outline the categories by which the Kwakiutl organize their thought and lives. His discussion of the "religious" or "symbolic" dimension of crests, names, and gifts, as well as the emphasis on the religious basis of aristocratic status contribute to an understanding of the Kwakiutl potlatch. One weakness of the work is its lack of a definition of religion and the separation of "religion" from other aspects of Kwakiutl culture, which are not subjected to analysis.

Walens follows Goldman in his attention to the "intellectual and philosophical aspects" of Kwakiutl ceremonialism and in his effort to demonstrate "corporate connections between humans, animals, and spirits" (1981:4). Walens provides an insightful analysis of the Kwakiutl ideas about personhood, food, eating and vomiting, as well as an interpretation of such potlatch gifts as furs, blankets, "coppers," and so forth. However, a failure to provide ethnographic data to support the argument about the "limited set metaphors" by which the Kwakiutl express their world view and ethos leaves the reader uncertain whether the metaphors discussed originated in the native culture or in the imagination of the anthropologist (cf. Powers 1983; Suttles 1984). Walens' reduction of Kwakiutl cosmology to a single metaphor of eating and being eaten is hardly satisfactory (cf. Goldman 1983).

A recent application of methods and concepts of Geertzian "symbolic anthropology" to the potlatch is found in the work of Seguin $(1984,1985)$. Unlike Walens, Seguin combines a reanalysis of existing ethnographies with archival research and fieldwork. Her reconstruction and analysis of the symbolic system underlying the Tsimshian potlatch traces the connections among the elements found in this ritual and in other aspects of Tsimshian culture. Her study reveals a complex "relationship between Tsimshian beliefs in reincarnation, traditional attitudes towards other realms of power, including ghosts, animals and supernatural beings, and the relationship between the individual and the source of the original power," that is, the paternal ancestral line (1985:24).

\section{the Tlingit potlatch in ethnographic literature}

In the literature on the Tlingit potlatch, description rather than analysis predominates. This is not necessarily a drawback, because the Tlingit ethnographers, beginning with the Russian priest Veniaminov (in the 1830s), managed to grasp the native view of the potlatch, that is, "regard and respect for the dead" (Swanton 1908:234). Having identified the ritual as the core of Tlingit ceremonialism, Veniaminov (1886:621-628), Swanton (1908), Emmons (1910; 1920-45), McClellan (1954), Olson (1967:58-69), and de Laguna (1972:606-651) discussed it in the context of the mortuary complex. Swanton, Emmons, McClellan, and de Laguna came closest to the indigenous ideology in their emphasis on what Emmons (1920-45, Ch. 6:24) has called the "religious aspect" of the potlatch, "a deep religious fervor in the worship of ancestry and communion with the dead." Sixty years later, de Laguna summarized the essence of the Tlingit potlatch as follows: 
the potlatch can be seen as part of the life cycle of an individual, since it always follows the death of some prominent person and is concerned primarily with honoring his memory. . . This concern with the dead is always present, even though the more apparent function of a potlatch may be to dedicate a new lineage house, to announce the assumption of a dead chief's title by his successor, or to honor and ennoble the children of a chief [1972:606].

All of the scholars mentioned above agree on the centrality of the potlatch in Tlingit culture, and on its ability to "bring together the most important aspects of Tlingit life" (de Laguna 1972:606). While mentioning its commemorative nature, Oberg (1973:127-128) and Olson (1967:111) emphasize its "social" aspects, following the tradition of Barnett and Drucker. The most recent work by Tollefson (1976:203-204) revives the functionalist position by focusing on the "economic" and "political" aspects of the potlatch."

My own analysis attempts to bring together the various approaches outlined above (with the exception of the ecological) and examines the Tlingit potlatch within a broader context of the mortuary/memorial complex. Reconstruction of the 19th-century potlatch is based on previous works by American anthropologists and other observers, on the relatively unused published and unpublished Russian accounts (Veniaminov 1886; Kamenskii 1906; and so on), and on data from archival sources. Material collected during fieldwork in several Tlingit communities in 1979-80 and 1984 is also used.

Contrary to Goldman (1975:24), Ringel (1979), Walens (1981:20), and some others, I believe that, despite significant changes in Northwest Coast cultures, the current potlatches retain many of the key features of the 19th-century ones, especially among the Tlingit. Data obtained through active participation in and observation of the potlatch complements the "memory ethnography" of the earlier works. Because of the focus of much of the Boasian anthropology on reconstructing the "traditional" native cultures, one rarely finds reference to the Tlingit potlatches of the 1930s through the 1950s, the time when Oberg, Olson, and de Laguna were conducting their research. Most ethnographers give the impression that they did not participate in Tlingit potlatches, and some of them probably did not. ${ }^{*}$ Consequently, many significant aspects of this ritual, including the behavior and experience of the participants, were left out."

I agree with Miller's recent criticism of the existing models of the potlatch as being "reductionist, focusing on only one or a few features" of this multifaceted phenomenon (1984:38). In this paper I develop a more holistic interpretation of the 19th-century Tlingit potlatch that combines an analysis of the native ideology and the actual interaction and relationships among the participants. Being especially interested in the meaning of the various exchanges between the hosts and the guests, I argue that each type of food and gift distributed among the latter had a distinct meaning related to the overall function and significance of the potlatch (cf. Rosman and Rubel 1971:179; Goldman 1975; Walens 1981). Unlike my predecessors, I examine not only the tangibles, but also the speeches, songs, and other performances exchanged among hosts and guests and argue that the interaction between them can be analyzed as a form of discourse conducted through the symbolic media of material objects, bodily movements, and words (cf. Seguin 1985:78).

I also argue that the dead played a significant, if not the central, role in the Tlingit and other Northwest Coast potlatches as well (cf. Wike 1952). ${ }^{10}$ Existing accounts indicate the significance of the mortuary potlatch in the Haida (Blackman 1977, 1982), Tsimshian (Garfield 1939; Adams 1973), and even Bella Coola (Mcllwraith 1948) and Kwakiutl (Drucker and Heizer 1967:130-132) cultures. While most other types of potlatches declined in the 20th century, the mortuary one survived, and, as Blackman suggests, "we may be seeing in the mortuary potlatch a more basic, more central . . . ritual, its roots firmly entrenched in the northern land possibly central-S.K.] areal expression of the Northwest Coast culture" (1977:51-52). The key role played by the dead in most potlatches thus demands that an analysis examine not only the living but the deceased participants as well (cf. Wike 1952:101; Goldman 1975 passim; Walens 1981:4). 
The Tlingit were divided into two matrilineal exogamous moieties, the Ravens and the Eagles (Wolves), further subdivided into matrilineal clans. Each clan possessed crests, origin myths, songs, and dances, which presented its sacred history and symbolized its members' collective identity. Clans also owned names (titles), subsistence areas, and other forms of tangible and intangible property. Many were not localized but were represented in villages by their segments (subclans), each occupying one or several houses. Each house was identified with a matrilineage, which also owned a stock of lands and ceremonial property. The society was ranked, with house heads and their immediate matrikin forming the aristocracy. Junior matrikin of the aristocrats constituted the commoners. Slaves, consisting of some impoverished Tlingit and their neighbors captured in warfare, were perceived as being outside the Tlingit society and were not granted full personhood (Kan 1982:101-102). Lineages and clans were ranked, but ranking was inexact and subject to dispute and reevaluation, ultimately tested in the potlatch.

The funeral began with the washing and dressing of the corpse in ceremonial garments depicting the crests of the lineage and clan of the deceased." The body was placed in the back of the house in a reclining position, knees drawn up and bound, hands placed on them. The deceased wore gloves or mittens, boots, and (a male?) was provided with a spear. Frequently he also wore a headdress representing his clan or house. Other regalia of the matrilineal group of the departed were placed near the body, along with personal possessions. The number of the deceased's matrikin affected by the death depended on his status and rank. A standard unit involved was the subclan. All of its members suspended their mundane activities and visited the house of the deceased several times throughout the wake. Most strongly affected were the lineage kin of the departed, who had to fast, cut their hair, paint their faces black, and observe other taboos. These mourners expressed their sorrow and honored the deceased by wailing, singing "crying songs" (gaax daasheeyi), and speaking to and about him. During the wake, the ghost was believed to remain in the house, and when it departed to the cemetery, there was a danger that it would take a beloved relative along.

In the meantime, the paternal/affinal relatives of the deceased (members of the opposite moiety) were busy preparing the funeral pyre, dressing, feeding, and comforting the mourners, and carrying out other practical tasks. The length and elaborateness of the wake were determined by the rank and status of the deceased and of his lineage and clan. A commoner's wake lasted for 4 days, while that of an aristocrat (aanyádi) could continue for 8 days. Every evening, affinal/paternal relatives of the deceased came into the house to comfort the mourners with speeches. They received tobacco, food, and some gifts, tokens of the much larger donations to be made to them in the potlatch (Shotridge 1917:106-108; Olson 1967:59-60). Food and tobacco were also burned as an offering to the matrilineal ancestors of the mourners.

The body was taken out through the back of the house or the smokehole and cremated. Some personal belongings of the deceased were cremated as well, while others were subsequently distributed among his lineage kin. The male "opposites" of the departed cremated the body, while the female ones collected the ashes and the bones, and placed them in a temporary container, a box inside a grave house. Following cremation, the matrikin of the deceased removed the signs of mourning, cleansed themselves, and conducted the first in a series of small feasts, in which they thanked their "opposites" and feasted them. Once again, food and tobacco were sent to the matrilineal ancestors of the hosts. The end of these feasts coincided with the arrival of the spirit of the deceased in the "village of the dead" (s'igeekáawu aani), but its final separation from the living did not occur until the memorial potlatch. The term s'igeekáawu aani (literally "village of the bones' people") was applied to the cemetery located behind the village of the living, as well as the distant, noncorporeal dwelling place of the spirits. The cemetery consisted of grave houses containing several boxes, each filled with the remains of a single person. Every clan's cemetery was located behind its houses, so that the "village of the dead" 
mirrored that of the living. Boxes with the remains of aristocrats were also often deposited in the back of mortuary poles. ${ }^{12}$

My analysis of the Tlingit funeral (Kan 1982:190-266), influenced by Van Gennep (1960), Hertz (1960), Turner (1967), and Huntington and Metcalf (1979), focuses on the transformation of the corporeal and the noncorporeal attributes of the deceased, the mourners, and the members of the opposite moiety involved in the funeral. In the course of the mortuary ritual, several elements constituting a complete human person in the Tlingit culture were separated from each other. The decaying corpse was a source of great danger for the living matrikin of the deceased. In the native theory of personhood (Kan 1982:45-80), a clear distinction was made between the temporary physical attributes, which I label the "outside," and the more permanent corporeal and noncorporeal ones, that I refer to as the "inside."13 The former included the skin and flesh, seen as the surface upon which the social identity and emotional state of the person were reflected. Representations of the social identity also appeared on ceremonial garments, seen as an additional layer of the "outside." Despite the preoccupation with the perfect state of the "outside," the "inside," consisting of the bones and several noncorporeal entities, was perceived as a more significant element controlling the "outside." In contrast to the "soft" and "wet" flesh, the bones were considered "solid," "dry," and "heavy," and occupied an intermediate position between the flesh and the spiritual entities. ${ }^{14}$

Cremation may be interpreted as a quick way of separating the polluted flesh (no longer controlled by the "inside") from the pure bones and releasing the noncorporeal entities of the "inside."15 The bones were "dressed" in blankets and placed inside a "house" in the "village of the dead." The spiritual entities included a ghost that dwelled with the bones, a spirit located in a noncorporeal replica of the house of the deceased in the distant "village of the dead," and another spirit that returned to this world to be reincarnated in a matrilineal descendant of the deceased. ${ }^{16}$ Cremation ensured that the spirit remained warm in the afterlife, while the fireplace inside the house of the living served as their medium of communication with departed matrikin, who depended on the food and gifts placed in it by the living.

Despite the pollution emanating from the corpse, the Tlingit displayed it in the most conspicuous part of the house, associated with the house chief (hit s'aati) and the sacred objects representing the lineage crests (at oowu). In the native view, the clothing put on the deceased equipped the spirit for a difficult journey through the interior forest to the "village of the dead," while the songs performed by the mourners "cleared the underbrush from its path" (McClellan 1975:373; Kan 1982:207). At the same time, the display of the corpse was described as "showing respect to the deceased" (Wallis 1918:80; Swanton 1908:429). The focus of the wake was on the social identity of the deceased (cf. Hertz 1960:77). The death of each member of a matrilineal group (particularly an aristocrat) caused a social crisis. Hence, the wake involved a collective assessment of the social career of the deceased and reiterated his ties with each member of his lineage or clan. The first stage in the transformation of the deceased into an ancestor (cf. Hertz 1960:79-80), '" the wake was a period of the greatest solidarity among the matrikin of the deceased, united in their common grief, and in what they called "love and respect" for the deceased. Their mourning attire underscored that unity, while deemphasizing the important distinctions and inequalities among the aristocrats and commoners, old and young, men and women. The transformation of the mourners during the funeral paralleled that of the deceased, consisting of the three stages of the rites of passage (Van Gennep 1960; see also Hertz 1960; Huntington and Metcalf 1979; Kan 1982:222-223). ${ }^{18}$

The mourners' behavior contrasted sharply with that of their paternal/affinal kin. While the former were passive, if not socially dead, the latter were engaged in handling the polluted corpse, and helping the mourners practically and morally. This enabled the mourners to concentrate on the pure "inside" (social persona, spiritual attributes) of the deceased, since their "opposites" dealt with the polluted "outside." By the end of the funeral, the mourners returned to normal, active life and became donors, while their "opposites" turned into the more passive 
recipients, a role they continued to play throughout the remaining rituals of the mortuary cycle, including the potlatch.

Thus the funeral reaffirmed the two fundamental principles of the Tlingit sociocultural order: matrilineal unity and solidarity, and the reciprocity between moieties. It began as a dramatic disruption of normal social life and ended with its restoration as well as reaffirmation of basic cultural values, including the "love and respect" between the living and the dead, and between affines. Finally, it allowed the mourners to display their sacred crests and perform the ancestral songs and dances that enhanced the status of their matrilineal groups. ${ }^{19}$

\section{memorial potlatch as the secondary treatment of the dead}

The funeral and subsequent memorial feasts did not complete the mortuary cycle. The remains of the deceased were not considered "finished" until a new container had been provided for them. This could be a new box, a new or repaired grave house, or a mortuary pole. The remains were "finished" by the same paternal/affinal relatives of the deceased who had earlier participated in his funeral. At the memorial potlatch they were remunerated for their services, while the matrikin of the deceased ritually ended their mourning. The ceremonial regalia, names, and other attributes of the deceased were bestowed upon his matrilineal descendants. Only those on the very bottom of the social hierarchy were not memorialized in a potlatch. The rest of the people were either honored in a special potlatch or included in the rites honoring their matrikin of higher rank.

The liminal nature of the period between the funeral and the potlatch was clearly expressed by the notion that the deceased had not yet found a permanent place in the "village of the dead," while his matrikin had not yet been released from mourning taboos, and were still considered indebted to their "opposites," who had helped them during the funeral. To refuse to give a potlatch was to risk illness and death, and to show a total lack of "love and respect" for one's matrilineal ancestors and "opposites."

By approaching the Tlingit potlatch as a secondary treatment of the dead, 1 incorporate the native view into the analysis and thus broaden its scope. I also suggest that the data indicate a similarity between this ritual and various forms of the secondary treatment of the dead found throughout the world (Hertz 1960; Bloch 1971; Huntington and Metcalf 1979; Bloch and Parry 1982).20

outline of the memorial potlatch The hosts' preparation for the potlatch included an accumulation of wealth and an observance of various rules similar to those imposed on persons preparing for a dangerous task requiring magical power and good fortune (laxeitl). Brothers-inlaw of the hosts (naa káani) were sent to invite the guests from distant communities, while the local guests were invited some time before the ceremony by the naa káani who stopped in front of their houses and called out their ceremonial names (titles)- hence the Tlingit term for the potlatch, ku.eex', from the verb ya-.eex', "to call out," "to invite.."21

The arrival of the guests was marked by mock battles and an exchange of dances and songs between the guests standing in their canoes and the hosts on the beach. Once the guests had landed, they were taken to the houses of the hosts' clan, where they stayed through the entire period of feasting and ceremonies, which lasted for at least a month. Preliminary rites included dancing, singing, and masked performances by the two sides, as well as the feasting of the guests by their hosts. The potlatch proper usually lasted 4 days. It began with the hosts "mourning their dead [matrikin] for the last time." Sad ("heavy") songs belonging to the mourners' clan were performed, tears were shed, and speeches of condolence were delivered by the guests, to which the hosts responded with speeches of gratitude. With this part of the ritual completed, the mood and behavior of the participants became less somber. The hosts now 
performed songs describing their ancestral crests (called "national songs" by the present informants) and displayed them in the form of ceremonial garments and other regalia. The guests were feasted several times, while some food was put in the fire for dead members of the hosts' clan, who were believed to take part in the potlatch. The guests told jokes to entertain the hosts and help them forget their sorrow. "Love songs" (kusixán daasheeyí) were also exchanged between the two sides.

The climax of the potlatch was the distribution among the guests of the gifts contributed by individual hosts. Before making his or her donation, each host was given an opportunity to deliver a speech or sing a song illustrating his or her relationship to the deceased and to thank the guests for their help. Just before the distribution of gifts, the hosts named members of their group, many of them youngsters. A small portion of the gifts was burned for the benefit of the donors' matrilineal ancestors. The name of each deceased member of the hosts' lineage or clan was called out, followed by the name of a particular guest who was to receive the gift. The dead received the noncorporeal essence ("inside") of the gift, and the living its corporeal form ("outside"). Having collected their presents and packed the leftover food, the guests thanked the hosts for their generosity, and performed a few dances and songs as a form of gratitude. Often they would stage a small return potlatch, distributing among their hosts a portion of the gifts they had just received.

\section{the potlatch participants}

the deceased The potlatch completed the distribution of the various attributes of the deceased among the several domains of the universe. The bones and the ghost finally found a permanent home in the cemetery, while the spirit became forever established in the distant "village of the dead." Another noncorporeal entity, the yaahai, returned to the living to be reincarnated in a matrilineal descendant of the deceased. His ceremonial title(s) or name(s) as well as festive attire depicting his lineage or clan crests were bestowed on his successor. The rebirth of the deceased and the death's failure to interrupt the continuity of the matrilineal group were dramatically expressed by addressing the new owner of the title or the regalia as if he were the deceased himself (Kan 1979-84).

In the potlatch, the mourners'/hosts' attention began to shift from the recently deceased person to other dead members of their matrilineal group, whose names were also invoked and who were also "warmed," "clothed," and "fed" through the fire. The key value of the unity and solidarity of the matrikin was thus confirmed, since the rite, which had begun as a memorial to a single person, became the main occasion for remembering, honoring, and helping the matrilineal ancestors of the mourners/hosts. Every member of the group was given an opportunity to mourn his or her own departed matrikin.

One of the most dramatic and effective forms for expressing the continuity between the generations of lineage or clan relatives were the "sad songs" (tuwunukw daasheeyi), also called "heavy songs" (yaadaali daasheeyi). Some were identical to those performed during the funeral, but others (the most sacred and valuable) were reserved for the potlatch. For example, one popular "sad song" of a Sitka clan is believed to have been composed by a woman of that group, after the canoe containing her baby had been carried away by the tide. The woman mourns her beloved child's death and compares it to the tragic deaths of several of her clan ancestors, killed while riding in a canoe in the early $1800 \mathrm{~s}$, during the war with the Russians (Olson 1967:44-45; Kan 1979-84). The image of the canoe carrying dead bodies links the two events. When the descendants of the song's author perform it during their potlatch, they lament the deaths of all of their matrikin, both the recently deceased and those of long ago, including the unfortunate infant and the brave warriors. Since kinship terms rather than personal names were used in most songs, and since many deaths resulted from the same causes, a mourner 
could usually find an appropriate song to express his or her sorrow about the loss of a particular clan relative (cf. de Laguna 1972:632).

The participation of the matrilineal ancestors of the hosts in the potlatch was emphasized throughout the ritual by invocation of their names and reference to their lives. The custom of inviting them to the potlatch was believed to have originated in ancient times, when Raven, the culture hero, was shaping the world into its present form. According to Veniaminov (1886:623-624), Raven once invited the dead to a feast and tried to feed them. However, they were able to consume only the food placed into the fire. After his guests had departed, Raven discovered that the food in their dishes remained intact. "This is why today the Tlingit have memorial feasts for their dead relatives in order to feed them, but with one difference: they throw just a little bit into the fire and [their living guests] eat the rest," concludes Veniaminov (1886:623-624).

The notion that everything given to the guests in the potlatch belonged to the dead member of the hosts' lineage/clan explains why the food and gifts have been referred to as "dying" or "being killed." ${ }^{22}$ Once the property had been collected and prepared for distribution, it could no longer be used by the donors, since that would bring great misfortune upon them. As one informant explained, "You can't touch that food, gifts, and money. They already belong to the dead" (Kan 1979-84). The presence of the dead accounts also for the taboo on continuing the potlatch proper into daylight hours. ${ }^{23}$ The association between the dead and the nighttime is not surprising, since animal and superhuman spirits were active at night, magic power was more accessible to humans after dark and, in comparison to this world, day and night in the "village of the dead" were reversed.

The potlatch played a number of important roles in the sociopolitical domain of Tlingit life, including the validation of claims to certain rank and status. However, the Tlingit themselves saw it first and foremost as a memorial ritual (de Laguna 1972:612; Kan 1979-84). Having no corporeal "outside," the dead were invisible, but through various forms of symbolic media they were, as one informant put it, "brought back to life." In the performance of the "heavy songs," the living not only described the lives of their matrilineal ancestors but ensured that the "voices of the dead could be heard." This seems to be more than a metaphor, since a number of informants said that they could see their beloved mothers and maternal uncles among the dancers and could distinguish their voices among those of the singers (Kan 1979-84).

The continuity between the living and the dead matrikin was made manifest in most of the ritual performances, but especially when the ancestral regalia and the "heavy" ceremonial names/titles were used. The garments passed from one generation of clan members to the next could be interpreted as the "outside" layer of the dead appropriated by their living descendants. The names were also perceived as tangibles placed on the living as clothing. Thus, according to Oison (1933-54, notebook 5:52), "Those to be reincarnated go to a place no one knows where and when they come back they carry (as a bundle) under their arm that same name which is therefore given to them." Names were said to be given "to the face" of the recipient (Johnson 1979:6). This notion was reinforced by the practice of rubbing some of the gifts to be distributed in the potlatch on the forehead of the recipient of a name. The Tlingit were concerned with preventing their names/titles from "dying out" and accomplished that by perpetually recycling them among their descendants. Each potlatch name/title, as opposed to a birth or a pet name, had a certain prestige and social value and indicated the rank of its holder (Olson 1967:48). According to Olson (1933-54, notebook 9:65), "A man who repays his debt may pay only the original amount but usually would pay back more for the honor of his name. But if the debt is passed on for a generation or more, a larger amount is always paid. Idea is not of interest but of honor of the name" [emphasis added]. ${ }^{24}$

The relationship between the living and the dead dramatized in the memorial potlatch was that of reciprocity. The living provided the dead with food, warmth, gifts, and, most importantly, love and remembrance. In return, the dead passed on their valuable names and other 
sacred possessions and prerogatives, used by the living to maintain and raise their rank, status, and prestige. ${ }^{25}$ Although this could not be called "ancestor worship" (contra Emmons 1910), the Tlingit did believe that the dead could not only help but harm the living with illness and death, if the latter did not remember, honor, and help them. As long as the dead were remembered by their living matrikin and could participate in their potlatches, they remained immortal and sat close to the fire in their noncorporeal houses (Swanton 1908:462). The forgotten ancestors, on the other hand, moved further and further away from the fire, suffered from hunger and cold, while their "houses" in the cemetery crumbled. Ultimately, the continuity of the matrilineal clan, as a cultural category, depended upon a human ability to remember.

the mourners as hosts Just as it is necessary to include the deceased in the analysis of the potlatch, it is essential to incorporate the native view of the ritual as the last public expression of the mourners' grief. Thus, in the 1980 s potlatches I witnessed, the hosts were encouraged by guests "not to hold back their tears" and "let all their sorrow out." This was accomplished through the mourners' performance of the four special "crying songs," one of their most treasured possessions. This singing was followed by the four prolonged oo sounds made by the mourners, said to "expel sadness from their toowú [mind/soul, "inside"]." The male mourners also struck the floor with their staffs four times, "putting all of their grief" into that act (Kan 1979-84; Olson 1967:61).

The Tlingit thought that emotions originated in the toowu and were expressed on the "outside" through tears, laughter, words, and facial expressions. Grief was perceived as a particularly powerful emotion, somewhat independent of human will and consciousness. According to Swanton (1908:437), "It is not through man's own will, but the way that Raven made people, that brings forth a new song, when people are called together after one has died." The "crying songs" were the most appropriate expression of grief, perceived as something tangible, which could be manipulated and expelled during the potlatch. Thus, in Olson's account, the mourners followed the singing of the four "sad songs" with the shedding of their coats (in lieu of blankets) and holding them before the fire to "dry their sorrow" (1967:62). The ritual was also seen as a way of strengthening the mourners' toowú. Their mood was expected to change and no more tears were supposed to be shed in public after that. In a recent potlatch, the hosts expressed this change by using two carved representations of their main crest, a certain type of salmon. At the beginning of the ritual, the two fish were hung on the wall with their heads pointing downward to represent sorrow; after the ceremony of "pushing away sorrow," their heads were turned upward, to make them "look happy" (Kan 1979-84).

In the expression of their sorrow, the hosts were unified. Throughout the potlatch, this solidarity was maintained and repeated in word and action. Thus, all of the hosts remained standing during the potlatch, occupying the front of the house, its least conspicuous area, so as to show their deference to the guests (Kan 1978). Every member of the hosts' group, regardless of rank, could express his or her feelings (de Laguna 1972:632-633).

The hosts were also united in their subsequent performances aimed at displaying their ancestral regalia and prerogatives. While justified as a show of "love and respect" for their ancestors, they were also intended to confirm the hosts' claims to their sacred possessions and to raise their status. As Olson (1967:59) notes, the potlatch was not a duty but a privilege. In fact, it was the only major opportunity for the display of the sacred crests (at oowu), the performance of songs, dances, and myths embodying the sacred history, identity, and destiny of the matrilineal group (its shagóon). A generous distribution of property accompanying this display increased the value of the crests. Thus, a distribution of $\$ 6000$, while displaying a headdress representing one of the hosts' major crests, was described as "killing $\$ 6,000$ to bring out the headdress" (Swanton 1908:442; see also Oberg 1973:125). In addition to displaying their old possessions, the hosts could validate their claims to new ones, including houses and lands. This was said to make the property and its owners "heavier," that is, increase their value and status 
by bringing them into direct contact with the wealth to be distributed to the guests. Thus, in a recent potlatch, money placed inside a headdress representing the hosts' major crest was later rubbed on the faces of those who were to be given names (Kan 1979-84).

These and numerous other examples indicate that actions aimed at raising the hosts' rank and status were justified as ways of honoring their matrilineal ancestors. The names of the dead were also invoked to restore peace, whenever conflicts occurred among the participants. I suggest that the "love and respect" of the living toward the dead served as an ideology, enabling the living to present actions aimed at raising their status as noble and morally correct. While statements of grief and love for one's ancestors, made by some of the hosts (especially the chief mourners), expressed sincere emotions, others used them as a rhetorical device in a struggle for power and prestige. At times the desire for prestige outweighed the mortuary/memorial purpose of the potlatch.

Nevertheless, it is incorrect to consider competition over rank, status, and prestige to be the only significant purpose of this ritual, as some scholars have done (Oberg 1973:124-125; Tollefson 1976:203-234). On the other hand, it would also be a mistake to restrict the analysis to the native ideology, which emphasized such commemorative aspects of the potlatch as "dignity, sympathy, high respect for all, with the exalted chief and the poor and lowly united in sorrow and honor for the ancestors" (de Laguna 1972:612). In my opinion, the complexity of the potlatch and its centrality in Tlingit culture and society resulted from a dialectical relationship between competition and cooperation, between the struggle for power and prestige on the one hand, and the "love and respect" for the ancestors on the other.

Thus, while united in their grief and pride in their clan's shagóon, the hosts competed with one another, and different categories of persons played unequal roles. For example, if the deceased was a house or a clan chief, several of his successors might compete for his title and position by trying to contribute the largest amount of wealth to his memorial potlatch and to play the leading role in it. Although most of the negotiations and debates between them would occur in private, the amount of wealth each would contribute and the order in which these individual presentations would be made served as a form of public competition. The head of the hosts made the last and the largest donation. Lower-ranking hosts could also use the wealth they contributed to compete with clan relatives of a similar rank. Although each host was supposed to contribute in accordance with his or her present rank and status, there always remained some room for competition and mobility. Such behavior was explained and justified as an effort to emulate the "illustrious precedents set by one's maternal uncles and grandfathers. However, the abstract standards of noblesse oblige or the legendary examples of dead ancestors were readily replaced by the challenging marks set by the present acts of fellow chiefs and clanmates" (de Laguna 1972:613). Bitter disputes between hosts also centered on the right to use crests and bestow valuable names on their immediate matrikin. Thus, if several houses acted as hosts, one of them would sometimes try to "grab" a high-ranking name before others had a chance to do so or would refuse to recognize the right of another house to display a particular crest (Oberg 1973:125; Kan 1979-84).

Among the hosts, the superiority of aristocrats over commoners, old over young, and men over women was stated by their respective location inside the house as well as the different tasks assigned to them. At the same time, the complementarity of different social categories was also expressed, for example, in the relationship between male and female styles of dancing. On the whole, the potlatch was dominated by the aristocrats, who acted as guardians of the ceremonial regalia, as song and dance leaders, as key orators, and as contributors of the largest amounts of wealth. The esoteric language used in the potlatch and the numerous metaphorical references to the participants' shagóon were used and understood mostly by the aristocrats who were specially trained for this ceremonial role. On the other hand, the cooperation of the entire matrilineal group of the hosts was necessary for the success of its potlatch, while the glory of 
the aristocrats reflected on their lower-ranking kin. Even a small contribution made by a poor host or a child was welcomed, and those with nothing to give were helped by their matrikin.

the opposite side as guests Much of the potlatch was focused on the relationships between hosts and guests, the latter activated by the same combination of competition and cooperation already discussed. To compensate one's "opposites" for the services provided during the funeral was just as important as the other functions of the potlatch examined above. This explains why today the Tlingit refer to this ritual in English as the "pay off (party)." In the potlatch guests continued to play their crucial role as mediators between the hosts and their deceased matrikin, since the spiritual essence of things given to the guests became the property of the dead. The guests also acted as representatives or impersonators of their own matrilineal ancestors, whose songs and dances they performed, and whom they frequently mentioned in their speeches. Finally, the presence of the guests was the prerequisite for the validation of the hosts' claims to their sacred crests.

In Tlingit society, relationships between matrilineal groups belonging to the different moieties were delicate and required a great deal of care to maintain balanced reciprocity. Feuds and wars between the Ravens and the Eagles broke out over minor insults and injuries. Unlike conflicts between members of a single moiety, these could not be settled informally, but demanded an elaborate peace-making ceremony before normal relations could be restored. One major prerequisite for peace was that the rank of all the slain members of one moiety should equal that of the other (de Laguna 1972:592-604).

Intermoiety relations in the potlatch must be viewed as a restoration of balance and a transformation of potential hostility into peace. This interpretation is supported by the use of war symbolism and rhetoric in the initial and sometimes later stages of the potlatch. Before the guests from another community could land in front of their hosts' houses, a mock battle occurred between the hosts on the beach and the guests standing in their canoes (Olson 1967:6162; Billman 1964:59). The ceremony began with the chief host appearing on the beach with a bow and arrows and wearing his war costume, and ended with his welcoming the guests by walking into the water towards them and having his junior male relatives carry them ashore in their canoes.

In comparison to the late 19th-century Kwakiutl, the Tlingit potlatch was characterized by relative peacefulness and a general lack of openly adversarial behavior. The killing of slaves and drowning of copper sheets and other valuables, labeled the "destruction of property" by anthropologists, was done not so much to challenge rivals, but rather to offer gifts to the hosts' matrilineal ancestors. At the same time, the aggressive rhetoric of some Tlingit potlatch speeches was not unlike that of the Kwakiutl potlatch described by Codere (1950). However, her interpretation of this phenomenon as a substitute for warfare does not seem to apply to the Tlingit, who waged war against and potlatched with each other throughout most of the 19th century. After the Americans put an end to warfare, the scale of the potlatch did increase, but that was due to the enrichment of the Tlingit from the fur trade and wage labor. A comparison of Tlingit and Kwakiutl potlatch rhetoric leads me to accept Drucker and Heizer's intepretation of the Kwakiutl references to war as a "verbalization of conflict," rather than a survival from an earlier era dominated by fighting (1967:125-129). ${ }^{26}$

The next issue to be discussed concerns the identity of potlatch guests. While existing evidence supports Rosman and Rubel's argument that the guests were divided into two competing groups (1971:51-53), they were not necessarily the only groups linked to the hosts through marriage. Swanton's (1908:435) data, the evidence used by Rosman and Rubel, does not show that the hosts' clan (the Chilkat Gaanax.ádi) had affinal ties only with two of the subclans invited to the potlatch (the Chilkat and the Sitka Kaagwaantaan). All of the existing data indicate that a Tlingit matrilineal group intermarried with more than two other groups (Olson 1967:7; Tollefson 1976:209-210; Kan 1979-84; and so forth). ${ }^{27}$ If this is the case, how then can we 
explain the dual division of the guests? First, the structure of the Tlingit house encouraged this: guests occupied the two sides, where they sat facing each other (Kan 1978). Second, out-oftown guests were always treated with somewhat greater deference than local ones. Since any major potlatch required the presence of the former, the division of the guests seems natural. If only local guests attended, they were divided along clan and lineage lines. The point is that it was the opposition itself and not the identity of the groups that mattered (cf. McClellan 1954:86). Competition between the two parties was expressed in dancing and eating contests, as well as in other performances, adding excitement to the ritual and underscoring the unity of the hosts.

The hosts carefully watched their guests to prevent competition from turning into serious conflict. The most effective way of restoring peace was for the chief host to appeal to the memory of his predecessor whose ceremonial attire he was wearing and whose crest(s) he was displaying. These objects were called "masterless things" ( $/$ s'aati át), which resembles the term for widow, I s'aati shaa (a woman without a master) (de Laguna 1972:614). This suggests that the violence between the guests threatened to turn the hosts into "widows," that is, to deprive them of potential spouses.

In addition to this dual division, the guests were also differentiated according to rank, age, gender, and the degree of relatedness to the chief hosts and the deceased. The guests' seating arrangement was the hosts' own statement of the current hierarchy within and between the kin groups of their "opposites." The ranking of guests was reconfirmed by the order of the distribution and the size of the gifts they received. In most cases, guests accepted the hosts' evaluation of their rank and status, but occasionally a guest showed displeasure and even attempted to leave. This called for a quick reaction from the hosts, who offered the offended person a different seat or increased the size of the gift. Thus, the potlatch became the main context in which members of the two moieties negotiated their positions in the social hierarchy, doing it not through open confrontation or argument, but by couching their actions in the rhetoric of "love and respect" for each other and for the ancestors.

Although the rank of a guest and the degree of closeness of his or her paternal/affinal relationship with the host were the main determinants of the nature and the size of the gift, the hosts' rhetoric emphasized that the feelings of "love and respect" between the donor(s) and the recipient were the determining factors. The main guests were paid especially generously for the services they had provided during the funeral and subsequent memorial rites, including the "finishing of the corpse." Of course, high-ranking persons and the close paternal/affinal kin of the lineage of the deceased were usually selected for those honorable tasks. Once again, the dead served as a vehicle for potlatch participants to justify their actions, lifting them above the level of mundane politics and personal likes and dislikes.

The special position of the hosts' close paternal/affinal relatives was emphasized not only by their places in the house and the size of gifts received, but also by assigning to them the prestigious task of serving as the hosts' naa káani. The latter were usually the brothers-in-law of the deceased and of the chief hosts, who performed the most delicate tasks of inviting the guests, escorting them to their seats, and counting and distributing the wealth amassed by the hosts. The most remarkable manifestation of this special relationship between close paternal/affinal relatives was the assistance provided to the hosts by their "fathers" and siblings-in-law. Swanton (1909:438) reported that a woman whose husband was preparing a major potlatch in the early 1900 s obtained $\$ 2000$ from her clan relatives in another community, thereby increasing her husband's contribution by 50 percent (cf. de Laguna 1972:640-641). The wife of the chief host could also refuse the money and gifts given to her with the words, "I give myself up for my husand" or "I give it [return the money and gifts] for the face of my husband" (McClellan 1954:84). According to McClellan (1954:84), only high-ranking women attempted this maneuver, which increased their own and their husbands' prestige. In current potlatches, financial help given to the hosts by their paternal/affinal kin is quite substantial and the practice itself 
seems more prevalent than in the 19 th century. An individual host may receive money from up to two dozen guests who wish to honor and show their "love and respect" to him. The amount received constitutes up to 30 percent, if not more, of the total monetary donation made by such a host. Of course, the guests making such contributions usually expect a generous return when the money is distributed. ${ }^{28}$

\section{forms of exchange}

The reciprocity between hosts and guests involved, in addition to tangibles, a flow of words, bodily movements, food, and gifts. The hosts dominated this exchange, since they had to restore the balance in their relationship with their "opposites," threatened by the hosts' indebtedness to them. Food and gifts flowed mainly from hosts to guests. On the other hand, guests played a greater role in the ceremonial oratory, since their role was to comfort the hosts and help them forget their sorrow, to which the hosts responded with words of gratitude.

the oratory of condolence and gratitude The potlatch oratory of condolence and gratitude was a complex genre, made into a true art form by the Tlingit. Since a detailed analysis of its structure, symbolism, style, and function has appeared elsewhere (Kan 1983), a brief summary is presented here.

The effectiveness of oratory was based on the notion that the spoken word had the power to heal and hurt, depending on how it was used. Guests' speeches were thus supposed to "smooth out," "strengthen," and "heal" the mourners" "inside" (toowú).

The structure of each speech was invariable, beginning with a "genealogical catalogue" (Dauenhauer 1975:186), which reaffirmed the speaker's ties with the different categories of the hosts and reminded them of the culturally appropriate emotions that characterized specific paternal/affinal relationships (for example, "love and pity" of fathers toward their children). The next step was a presentation of an episode, usually from the myths of the speaker's clan, which involved a human being or an animal in mortal danger and his miraculous deliverance, thanks to a human or a superhuman helper. The hosts' sorrow was linked to the protagonist's suffering, the guests' love and compassion to the actions of the mythical helper. The opposition between the grief and the absence of grief was metaphorized and repeated by a series of oppositions involving physical conditions frequently experienced by the Tlingit, such as hunger/eating, darkness/light, wet/dry, war/peace, and so on. The speaker could dramatize the healing effect of his words by using a crest of his clan to "save" the story's protagonist. For example, if the frog was his crest, he could say that the frog had swallowed up the mourners' sorrow. He could also strengthen the message by invoking his own matrilineal ancestors, saying that they were the ones helping the hosts. The references to the speaker's own matrilineal ancestors also reminded the hosts that their guests had previously suffered similar losses and hence could better understand their feelings. A condolence speech ended with a repetition of the opening genealogical catalogue.

The hosts interrupted the condolence speeches with their own exclamations of agreement and approval, and later thanked the guests and reiterated the message of their speeches in their own statements. The structure of the latter was the same as that of the guests. The words of the guests were said to "have healed" the mourners, "covered them with warm blankets," and "brought them good fortune" (laxeitl). The metaphors of the condolence oratory linked the past and the present, denying death the power to disrupt the process of social reproduction (Kan 1983:53-56).

At the same time, potlatch oratory allowed the participants to invoke their ancestral history, crests, and other sacred possessions. Thus, as with other forms of symbolic action involved in this ritual, it delivered messages of "love and respect" between relatives, as well as competition 
and the desire to increase their rank and prestige. This multivocality characterizes the other types of ritual exchange discussed below.

the "love songs" The solemnity of the condolence oratory and especially the "crying songs" contrasted sharply with the mood of the "love songs" (kusixan daasheeyi), also called "songs about the children of the clan" (naa yátx'i daa sheey'i). These were sung by the hosts, after the completion of the sad portion of the potlatch, when the hosts began to entertain the guests and to express their gratitude. A Tlingit "love song" addresses the children of the singers' clan, that is, those members of the opposite moiety whose fathers are their clan relatives. Thus, if the hosts were members of the Kaagwaantaan clan, they would sing about the "children of the Kaagwaantaan." (They could also mention the children of other clans of their moiety.)

To address a Tlingit as a "child" of his or her father's clan was meant to flatter and please him or her. The category of a clan's "children" included the singers' actual or potential spouses. Thus the "love" referred to in these songs included the feelings of fathers toward children as well as the love between men and women. As Dauenhauer points out,

The term "love" is used here also to mean respect. Love songs may be to a person of the opposite sex, but they may be in a deeper sense directed to one's own family [paternal kin], regardless of sex. Although the song may function on different emotional levels, the pattern will be structurally the same IDauenhauer 1975:153].

Many "love songs" were composed by persons expressing their feelings toward spouses and sweethearts, but the latter were never mentioned by name: the plural form of the word "child" was instead used. Thus, a particular "child" of the composer's clan was inseparable from his or her own clan, and love and social identity were linked together. As Dauenhauer (1975:153) puts it, personal emotion was expressed to a specific individual by a specific individual, but the relationship was controlled by the marriage rules.

The clan identity of the addressees remained unknown until the latter responded by joyfully dancing in a special style. This acknowledged their paternal ancestry and returned the "love and respect" to the singers. The guests also responded with a few "love songs" of their own, prompting the hosts to react in a similar manner.

"Love songs" underscored the cultural emphasis on "love" between "opposites," seen as being responsible for sexual and social reproduction. They stressed the lighter side of intermoiety relations, contrasting sharply with the war rhetoric exchanged earlier between hosts and guests. ${ }^{29}$ "Love songs" were more than a simple relief from the solemnity of much of the potlatch, although the importance of participants' enjoyment should not be underestimated. The use of images that alluded to heterosexual love in a ritual marking the end of mourning is not surprising. This was, after all, a celebration of life's victory over death, a common theme of mortuary rites throughout the world (cf. Huntington and Metcalf 1979; Bloch and Parry 1982).

feasting and the distribution of gifts The feelings and attitudes of the hosts to the guests were also expressed through the distribution of food and gifts, the climax of the potlatch. The spectacular nature of the distribution of huge amounts of fish, meat, fish oil, berries, animal skins, blankets, and so forth, has been the subject of a number of analyses (for example, Benedict 1934; Suttles 1960). However, "this powerful quantitative impression" of the wealth has "obscured for many scholars the traditional . . . regard for both the quantity and the symbolic significance of each item" (Goldman 1975:134). ${ }^{30}$

The Tlingit themselves referred to the feeding of guests and showering them with furs (or blankets) as giving them physical strength (latseen) and warming them by covering them up (Olson 1967:19). These images were appropriate, since the hosts were, in fact, reciprocating the guests' earlier efforts to "warm" their "inside" and to "give it strength." Thus, the spiritual comfort was exchanged for the physical comfort and strength. Feeding the guests was an effective way of demonstrating one's feelings toward them, since gifts of food were a standard form 
of exchange between affines. Gifts bestowed on a person by his or her paternal/affinal kin outside the potlatch were also referred to as "blankets" (McClellan 1975:638). The special nature of these gifts as expressions of the hosts' "love and respect" for the guests was emphasized by physical contact. As mentioned above, gifts were rubbed on the donors' foreheads or wrapped around them, thus absorbing part of the donors' selves. This quality of the potlatch gift was well understood by Mauss (1967:10; cf. Walens 1981:80).

Feeding the guests and giving them gifts was also an expression of the hosts' generosity. No object given could be refused, since its spiritual essence belonged to the dead. To refuse meant to "close the door to the land of the dead" (Olson 1967:66), that is, to disrupt the reciprocity between the living and their ancestors. Thus, food and gifts linked the four categories of the potlatch participants: the hosts, the guests, and the deceased matrikin of each. To this day, the favorite food of the hosts' deceased clansmen is served in the potlatch. Some of it, specially marked as belonging to the dead, is put in dishes called gan kas' $\underline{x}^{\prime} i$ (or $x^{\prime}$ aan kas ${ }^{\prime} \underline{i}{ }^{\prime} i$ ) (fire dish) and given to close paternal/affinal relatives of the deceased hosts. The donor announces their names as well as those of the guests who received the dishes. In the past some of this food was burned, but today all of it is consumed by the recipients (Kan 1979-84; Worl 1984).

The symbolism of the animal skins and furs, as well as the blankets that replaced them as primary potlatch gifts by the end of last century, also pointed to a special relationship between the living and the dead. The act of giving them was called to "dress the guests" (Emmons 192045, Shukoff's Account:9) or to "put on something," and it elicited statements of gratitude from the guests, who thanked the hosts for "warming" them (Olson 1967:65)." It is possible that originally furs and blankets were actually placed on the guests, as is still done by the Koyukon Athabascans (distant relatives of the Tlingit), in their memorial rites. Among them, the guests who represent the dead are dressed by the mourners/hosts on the last day of the potlatch and their departure is described as the dead leaving their relatives forever (Carlo 1978:67).

The potlatch gifts and food had other meanings appropriated by the hosts in their efforts to raise their rank, status, and prestige. In Tlingit society, presenting a person with a gift was not necessarily an act of "love and respect." It could also be a request for a larger return gift as well as a way of placing the recipient in an inferior position vis-à-vis the donor (cf. Oberg 1973:99). ${ }^{32}$ Challenged by their hosts' generosity, the guests tried to match or exceed it in their own potlatch, in which the former acted as guests.

Another message carried by potlatch gifts was the donors' success in subsistence activities, which reflected their skills and magical power. Thus, according to one of Emmons' informants, a chief host might sometimes boast of his hunting achievements and the wealth that they had brought him (1920-45, Shukoff's Account:8-9).

The hosts tried to create the impression of an endless supply of food, including forcing on the guests more than they could consume. The latter were expected to overeat and vomit, and then were given additional gifts for their "suffering." If nobody vomited, it spoke badly about the hosts and their food (1920-45, Shukoff's Account: 8-9). "Finally, the practice of providing the guests with extra food to take home served as a reminder of the hosts' generosity and power long after the end of the ceremony.

Similar to potlatches in neighboring coastal societies, the Tlingit potlatch involved several types of gifts, some of them reserved for the aristocracy (cf. Goldman 1975:136-137). Along the entire Northwest Coast, slaves and copper sheets ("coppers," Tlingit tinna) were the most valuable, their symbolism similar but not identical to that of other ritual prestations. Both slaves and coppers were brought from the "outside," the former through warfare with the neighbors to the south, the latter through trade with the interior Athabascans and later with Europeans (Keithahn 1963b). Their acquisition and distribution were controlled by the aristocracy. Neither slaves nor coppers were used for utilitarian purposes, since the former were purchased just before the potlatch and did not do any work (Oberg 1973:116) and the latter were reserved exclusively for ceremonial exchanges. Slaves, like other gifts, were placed in physical contact 
with the hosts' crests: they were killed with a special club depicting their master's crest, or held a rope tied to a headdress owned by their master (Olson 1967:63). The freeing of slaves, which increased in the postcontact period due to European pressure, was equivalent to killing them, since both acts made them socially dead (freed slaves had to leave their owner's community; cf. Goldman 1975:54). The slaves sacrificed in the potlatch became the servants of the hosts' matrilineal ancestors, while those given away became the guests' property. The spirits of the latter most likely became the property of the dead as well.

Coppers were the most expensive gifts, their value measured in several slaves. Like aristocrats, they were described as being "heavy," "hard," and "shiny." They were the most highpriced gifts exchanged between the families of a bride and groom. Several myths described coppers as "everlasting living things" and their origin was associated with the sun (Swanton 1909:252-262). They often had their owner's crest depicted on their surface, and each copper had a central " $T$ " cross segment called the "backbone" (Keithahn 1963b:59; Olson 1933-54, notebook 10:34). Coppers were usually drowned rather than thrown in the fire and, like human bones, were "heavy," indestructible, and contained their owner's spiritual essence (Billman 1964:59). Coppers and slaves were the only gifts requiring a return prestation of equal or greattr value (Olson 1967:66-67). Ultimately these two categories of potlatch gifts represented the aristocrats' control over life and death, since the latter could either kill them or give them away, that is, "spare their lives."

The discussion of the symbolism of the various forms of the potlatch exchange shows that songs, dances, and speeches, as well as food and gifts, served as a code for communication between hosts and guests. The various messages sent repeated the themes of competition and cooperation that, as I have demonstrated, characterized the entire potlaich. These various forms of symbolic media allowed the participants (particularly hosts) to mask assertions of superiority and make them appear to be statements about "love and respect." At the same time, they served as aesthetically powerful forms for expressing gratitude and other emotions that strengthened the cooperation and harmony among the participants.

\section{conclusion}

In this analysis of the symbolism as well as the sociology of the Tlingit potlatch, I have demonstrated its internal symbolic logic and linked it to various symbolic premises in other aspects of the Tlingit sociocultural order.

The study clearly shows the key role played by the dead in the Tlingit potlatch, both as participants and as a source of sacred values, an ideology used by the living to explain and justify their behavior. ${ }^{35}$ The potlatch periodically imposed order on the flow of social life, and provided temporary agreement among members of society about their relationships and their relative positions in a social hierarchy. The ritual was characterized by a dialectical relationship between competition and cooperation, which both united and differentiated its participants.

Beliefs about the dead and the desire to honor and emulate them both encouraged and limited competition, and reconciled such contradictory ideological principles as matrilineal solidarity and social hierarchy, and cooperation between affines and intermoiety competition. It also prevented conflicts generated by the social praxis from undermining the fundamental cultural values and structural principles. The ability of the potlatch to serve as the key link between the "thought-of" and the "lived-in" sociocultural order explains its centrality in 19th-century Tlingit life, as well as its survival into the present, despite years of criticism from missionaries and government officials and significant changes in the native culture and society.

The potlatch could not have played this central role in Tlingit life if it did not have a strong emotional effect on its participants. Although the data available on the 19th-century potlatch is insufficient for a detailed analysis of this aspect of the ritual, some existing accounts and 
information derived from current potlatches indicate that such powerful emotions as grief, joy, love, and so forth were a significant part of the participants' experience. Just as competition and cooperation existed in a dialectical relationship, so did positive and negative emotions. By wearing the regalia of their ancestors, performing their songs and dances, and giving and consuming objects created through hard work, the actors experienced fundamental cultural values as personally held orientations.

I suggest that the analysis presented here could be applied to other Northwest Coast potlatches and ceremonies, and that the role of the dead in them has, so far, been neglected or underestimated. A considerable amount of data on the Kwakiutl, Tsimshian, Haida, Bella Coola, and other potlatches could be used to generate more holistic interpretations. ${ }^{36}$ Much work remains to be done and we are fortunate that, despite the loss of some of their "religious" aspects, present-day Northwest Coast potlatches are "alive and well," still linking the living and the dead through various forms of ceremonial exchange and strong emotional bonds (cf. Holm 1977; Kenyon 1977; Blackman 1977; Stearns 1977; Miller 1984; Seguin 1985).

\section{notes}

Acknowledgments. The research on which this paper is based was carried out with the support of a grant from the Melville and Elizabeth Jacobs Fund of the Whatcom Museum of History and Art and the Faculty Fund of the College of Literature, Science, and the Arts at the University of Michigan. Portions of the paper appeared in my Ph.D. dissertation, which was read and commented on by Raymond D. Fogelson, George W. Stocking, Jr., Nancy D. Munn, and Jean Comaroff. The present version has benefited from helpful editorial comments and suggestions made by Margaret B. Blackman. I am grateful to all of these scholars, as well as to the editor and the reviewers of the American Ethnologist.

'The category "potlatch" is a creation of Europeans (including anthropologists). As Goldman points out in a discussion of Kwakiutl ceremonialism (1975:131), "There never were, at least in precontact days, such events as 'potlatches.' Rather, there were specific ritual occasions commemorating marriage, death, the construction of a house, investiture of an heir," and so forth. However, since many Northwest Coast ceremonies did share basic features, and because the Indians themselves have incorporated the term "potlatch" into their vocabulary, I will use it in this paper.

${ }^{2}$ Another critique of the ecological hypothesis was Adams' (1973) work on the Gitksan potlatch, which argued that the potlatch instead effected the redistribution of people over time to scarce resources.

'On the basis of one genealogy, Rosman and Rubel concluded that the Tlingit had a system of prescriptive FZD marriage, dismissing de Laguna's (1952) observation that a man's FZD was often his MBD as well.

${ }^{4}$ Structuralist models of Northwest Coast marriage systems fail to distinguish between ideal rules and actual practice, and also neglect the native view. Genealogies I have collected (Kan 1979-84) indicate that a Tlingit clan was linked through marriage not to one or two but several clans (cf. Tollefson 1976:108, 209). Although marriage between a man and his MBD/FZD was the ideal, migrations, depopulation, the need to establish new alliances, and other factors influenced the selection of spouses.

'Their argument, based on a single reference in Swanton (1908:435), ignores more detailed accounts of the potlatch by Olson (1967:58-69), McClellan (1954), and others.

"The Tlingit did not worship the dead but treated them with what they called "great respect."

${ }^{7}$ According to Tollefson (1976:22), the potlatch provided "an arena in which economic transactions could take place with a reasonable assurance that the investment would be secure and eventually returned." This restatement of Oberg's view (1973) assigns the potlatch to the domains of "politics" and "economics," and does not add anything substantial to the discussion.

${ }^{8}$ Emmons $(1910 ; 1920-45)$, a notable exception, did observe several potlatches. Unfortunately, he never provided a systematic account of the ritual.

'Elsewhere in Northwest Coast ethnology, lack of direct exposure to the potlatch often led to somewhat distorted views, in which theory tended to overwhelm the ethnography. A number of ecological, psychological, structural, and symbolic analyses failed to escape this pitfall. By focusing exclusively on the ideological aspects of the Kwakiutl potlatch, for example, Goldman and Walens almost totally ignored competition between the participants, the hosts' efforts to raise their rank and status, and other important aspects of the "sociology" of the potlatch. Taken to its extreme, such symbolic analysis of the potlatch seriously distorts its nature. Walens (1982:188-189), for example, suggested that "it was the purpose of the potlatch, not to make a profit, but to lose wealth for the benefit of others, to obtain spiritual purity through philanthropy."

"According to Wike (1952:98):

a continuity in the relationship of the dead to the living is one important reflection of the familiar Northwest Coast emphasis upon inherited position, ancestral pride, and the recognition of genealogies. The 
nature of this continuity is structured by the belief that the rewards and the status ranking of real life are maintained or intensified in life after death. Existing along with these beliefs . . . are ideas that physical and ritual contacts with the dead will insure personal success.

"For a detailed reconstruction of the 19th-century Tlingit funeral see Kan (1982:156-266). The best accounts of this ritual are by Emmons (1920-45, Ch. 6:14-25), Olson (1967:58-66), and de Laguna (1972:531-547), although all of them focus on the funerals of aristocratic males. However, for the purpose of my study, these are the most important rites, since they were the most elaborate and served as the model for those of the rest of the population. This explains the use of the male pronoun in my paper.

${ }^{12}$ The origin and evolution of Tlingit mortuary architecture is a complex issue that has not been fully resolved yet. See Keithahn (1963a), de Laguna (1972:539-545), and Kan (1982:184-187, 1985).

${ }^{13} \mathrm{~A}$ structural analysis of the Tlingit model of the world (Kan 1978; 1982:163-171) revealed the centrality of the "inside" $/$ "outside" opposition. The "inside" was usually positively marked and associated with the Tlingit people, the village, the warmth of the fire, dryness, abundance of food, and so forth. The "outside" was associated with the non-Tlingit, the dangerous domains of the forest and the sea, cold, wetness, famine, and so on. The Tlingit had to venture into the "outside" to obtain wealth and superhuman power, but preferred to return to the safety of the "inside."

14"Heaviness" was also associated with aristocratic status, moral righteousness, and sacredness (Kan 1982:48-51, 98-115).

"There is some evidence that the person's "inside" (spiritual attributes and bones) was provided by maternal ancestors, while the "outside" (for example, facial features) by the maternal as well as the paternal ones.

"The data on Tlingit beliefs about noncorporeal attributes of the human being is sketchy and contradictory. In addition to the three major spiritual entities already mentioned, there were others, such as the breath, the toowú (mind, feelings, thoughts), and a spirit that reincarnated in a matrilineal descendant of the deceased (Kan 1982:59-71); see also de Laguna (1972:758-771) and Emmons (1920-45:Ch. 6).

17According to Emmons (1916:17), the most important painting on the face of the deceased was the crest of his moiety. This suggests that in death the Tlingit rose above lineage and clan identity, and returned to primary affiliation with the moiety. This paralleled the journey of the spirit of the deceased back in space (toward the interior) and in time (retracing the route followed by the ancestors said to have migrated from the interior down to the coast).

${ }^{11}$ The mourners' behavior was also believed to affect their future. If they followed all the rules, they were to become wealthy and live longer. This was the "positive aspect of liminality" discussed by Turner (1967).

${ }^{19} \mathrm{Cf}$. Hertz 1960; Huntington and Metcalf 1979:93-118; and Weiner 1976:85-86 on the emphasis on "life values" in death-related rituals.

${ }^{20}$ The Tlingit treatment of the remains of the dead bears a special resemblance to those of such northern Athabascan groups as the Carrier (Jenness 1943:534) and the Kutchin (Hardisty 1866:319), who were probably their distant relatives.

${ }^{2}$ This sketch of the Tlingit potlatch is based on Swanton (1908:434-443), Olson (1967:58-69), MCClellan (1954), de Laguna (1972:606-651), and Kan (1979-84, 1982:268-279).

${ }^{22}$ Coldman (1975:245) presented linguistic evidence from Kwakiutl suggesting a similar concept: the verb yaxwede (to give away property) is related to yaq (to lie down, dead body), and yaqwe (to be beaten, to lie dead).

${ }^{23}$ If it could not be completed before sunrise, the participants had to sing a special song that asked the Raven to allow them to go on.

${ }^{24}$ Several recent symbolic analyses of Tsimshian and Kwakiutl cultures suggested that the people were given to eternal names, rather than the other way around, because "the name is an institution or the soul of a corporation that exists forever" (Miller 1984:29; cf. Goldman 1975:37; Walens 1981:65; Halpin 1984; Seguin 1984:114-115).

${ }^{25} \mathrm{Goldman}$ came to a similar conclusion in his analysis of the relationship between the living and the dead in Kwakiutl culture (1975:197).

"McClellan was the first to note the "strong stress on symbolized warfare" in the Tlingit potlatch (1954:96).

${ }^{27}$ In the case of the Chilkat Gaanax.ádi, their spouses were selected from the Chilkat Dakl'aweidi and other clans and subclans, both local and nonlocal.

${ }^{26}$ I do not know yet whether this practice became more popular in this century, with the strengthening of ties within the nuclear family, or whether my predecessors simply failed to report it fully. In any case, this reversal of the flow of the potlatch wealth is an interesting new dimension of the Tlingit potlatch that has not received sufficient attention.

${ }^{29}$ This explains why "love songs" were used during the ceremonies that reestablished peace between groups belonging to the opposite moieties.

${ }^{30}$ The work of Goldman (1975), Walens (1981), and Seguin $(1984,1985)$ has finally addressed the issue of the symbolism of the potlatch gifts.

${ }^{31} \mathrm{C}$. the guests' use of pieces of blankets and cloth received at potlatches to make clothing.

${ }^{32} \mathrm{Cf}$. Walens' interpretation of the Kwakiutl food giver as superordinate and the food receiver as subordinate (1981:80ff.).

${ }^{3}$ Walens' analysis of the symbolism of vomiting in Kwakiutl culture might be applicable to the Tlingit potlatch (1981:16-17). According to him, vomit, like fire, does not destroy, but transubstantiates, and is 
thus a paradigm of transformation and rebirth. If the Tlingit guests, like the Kwakiutl, vomited into the fire, the food thus returned could immediately reach the dead.

${ }^{34}$ The data on coppers from other Northwest Coast cultures is more extensive than the Tlingit material. Goldman (1975 passim) suggests that Kwakiutl coppers were associated with blood, salmon, sun, and fire. Coppers had the shape of a human torso and were carried like children. They died and were reborn like human beings. The most honorable way to kill a copper was to dismember it (Walens 1981:148-149). Goldman calls it an "overloaded and hence elusive symbol," which synthesized all forms and realms of life (1975:225). The most remarkable was an association between coppers and bones of the dead chief of the host group, mentioned in several accounts of the Kwakiutl (Drucker and Heizer 1967:137), Tsimshian (Garfield 1939:238), and Bella Coola (Mcllwraith 1948:252) potlatches.

${ }^{35} \mathrm{Cf}$. Weiner's (1976:56) discussion of the role of the dead in the Trobriand system of ceremonial exchange.

${ }^{36}$ Many aspects of the potlatch that continue to puzzle anthropologists might be understood if their symbolism was examined within the context of the broader sociocultural order. Thus, the famous destruction of wealth in the late 19th-century Kwakiutl potlatch might have had its roots in an effort to supply the ancestors with food and gifts (cf. Piddocke 1965:257; Wike 1952).

\section{references cited}

Adams, John W.

1973 The Gitksan Potlatch: Population Flux, Resource Ownership and Reciprocity. Toronto: Holt, Rinehart \& Winston.

Adams, John W., and Alice B. Kasakoff

1973 Review of Feasting with Mine Enemy: Rank and Exchange Among Northwest Coast Societies, by Abraham Rosman and Paula Rubel. American Anthropologist 75:415-417.

Barnett, Homer G.

1938 The Nature of the Potlatch. American Anthropologist 40:349-358.

Benedict, Ruth F.

1934 Patterns of Culture. Boston: Houghton Mifflin.

Billman, Esther

1964 A Potlatch Feast at Sitka, Alaska. Anthropological Papers of the University of Alaska 14(2):5564.

Blackman, Margaret

1977 Ethnohistorical Changes in the Haida Potlatch Complex. Arctic Anthropology 14:39-53.

1982 During My Time. Florence Edenshaw Davisona, a Haida Woman. Seattle: University of Washington Press.

Bloch, Maurice

1971 Placing the Dead. London and New York: Seminar Press.

Bloch, Maurice, and Jonathan Parry, eds.

1982 Death and the Regeneration of Life. Cambridge, England: Cambridge University Press.

Carlo, Poldine

1978 Nulato: An Indian Life on the Yukon. Fairbanks, AK: N.p.

Codere, Helen

1950 Fighting with Property. American Ethnological Society Monograph No. 18. Washington, DC: American Ethnological Society.

Dauenhauer, Richard L.

1975 Text and Context in Tlingit Oral Tradition. Ph.D. dissertation. Department of Comparative Literature, University of Wisconsin-Madison.

de Laguna, Frederica

1952 Some Dynamic Forces in Tlingit Society. Southwestern Journal of Anthropology 8:1-12.

1972 Under Mount Saint Elias: The History and Culture of the Yakutat Tlingit. Smithsonian Contributions to Anthropology, Vol. 7, 3 parts. Washington, DC: U.S. Government Printing Office.

Drucker, Philip, and Robert F. Heizer

1967 To Make My Name Good: A Reexamination of the Southern Kwakiutl Potlatch. Berkeley: University of California Press.

Emmons, George

1910 The Potlatch of the North Pacific Coast. The American Museum Journal 10(7):229-234.

1916 The Whale House of the Chilkat. Anthropological Papers of the American Museum of Natural History 19(1):1-33.

1920-45 Unpublished Manuscript on Tlingit Ethnography. New York: American Museum of Natural History, Archives.

Garfield, Viola

1939 Tsimshian Clan and Society. University of Washington Publications in Anthropology 7(3):167340. 
Goldman, Irving

1975 The Mouth of Heaven: An Introduction to Kwakiutl Religious Thought. New York: Wiley.

1983 Review of Feasting with Cannibals: An Essay on Kwakiutl Cosmology, by Stanley D. Walens. American Ethnologist 10:615-616.

Halpin, Marjorie

1984 Feast Names at Hartley Bay. In The Tsimshian. Images of the Past: Views for the Present. Margaret Seguin, ed. pp. 57-64. Vancouver: University of British Columbia Press.

Hardisty, W.

1866 The Loucheaux Indians. In Smithsonian Institution Annual Report for the Year 1866. pp. 303327. Washington, DC: U.S. Government Printing Office.

Hertz, Robert

1960 Death and the Right Hand. R. and C. Needham, transl.; E. E. Evans-Pritchard, introduction. New York: Free Press.

Holm, Bill

1977 Traditional and Contemporary Kwakiutl Winter Dance. Arctic Anthropology 14(1):5-24.

Huntington, Richard, and Peter Metcalf

1979 Celebrations of Death. Cambridge, England: Cambridge University Press.

Jenness, Diamond

1943 The Carrier Indians. Bureau of American Ethnology Bulletin 133, Anthropological Paper No. 25. Washington, DC: U.S. Government Printing Office.

Johnson, Andrew P.

1979 Kaax'achgook. College, AK: Tlingit Readers, Inc. and Alaska Native Language Center.

Kamenskiī, Anatolii

1906 Indiane Aliâski (Tlingit Indians of Alaska). Odessa, Russia: Fesenko Publishing House.

Kan, Sergei

1978 The Winter House in the Tlingit Universe. M.A. thesis. Anthropology Department, University of Chicago.

1979-84 Ethnographic Notes from 14 Months Among the Tlingit Indians of Southeastern Alaska. (Unpublished $\mathrm{ms}$. in author's possession.)

1982 "Wrap Your Father's Brothers in Kind Words": An Analysis of the Nineteenth-Century Tlingit Mortuary and Memorial Rituals. Ph.D. dissertation. Anthropology Department, University of Chicago.

1983 Words That Heal the Soul: Analysis of the Tlingit Potlatch Oratory. Arctic Anthropology 20(2):47-59.

1985 Memory Eternal: Orthodox Christianity and the Tlingit Mortuary Complex, 1840-1940. (Unpublished ms. in author's possession.)

Keithahn, Edward L.

1963a Burial Customs of the Tlingit. The Alaska Sportsman 29(4):18-19, 33-36.

1963b Origin of the "Chief's Copper" or "Tinneh." Anthropological Papers of the University of Alaska 12:59-78.

Kenyon, Susan $M$.

1977 Traditional Trends in Modern Nootka Ceremonies. Arctic Anthropology 14(1):25-38.

Mauss, Marcel

1967 The Gift, Forms and Functions of Exchange in Archaic Societies. Ian Cunnison, transl.; E. E. Evans-Pritchard, introduction. New York: Norton.

McClellan, Catharine

1954 The Interrelation of Social Structure with Northern Tlingit Ceremonialism. Southwestern Journal of Anthropology 10:76-96.

1975 My Old People Say. An Ethnographic Survey of Southern Yukon Territory. 2 parts. National Museum of Canada Publications in Ethnology, No. 6(1-2).

Mcllwraith, T.F.

1948 The Bella Coola Indians. 2 vols. Toronto: University of Toronto Press.

Miller, Jay

1984 Feasting with the Southern Tsimshian. In The Tsimshian. Images of the Past: Views for the Present. Margaret Seguin, ed. pp. 27-39. Vancouver: University of British Columbia Press.

Oberg, Kalervo

1973 The Social Economy of the Tlingit Indians. Seattle: University of Washington Press.

Olson, Ronald L.

1933-54 Unpublished Fieldnotes on the Tlingit of Southeastern Alaska. Archives, Bancroft Library, University of California-Berkeley.

1967 Social Structure and Social Life of the Tlingit Indians in Alaska. University of California Anthropological Records 26:1-23.

Piddocke, Stuart

1965 The Potlatch System of the Southern Kwakiutl. Southwestern Journal of Anthropology $21: 244$ 264.

Powers, William K.

1983 Review of Feasting with Cannibals: An Essay on Kwakiutl Cosmology, by Stanley D. Walens. American Anthropologist 85:203-204. 
Ringel, Gail

1979 The Kwakiutl Potlatch: History, Economics and Symbols. Ethnohistory 26:347-362.

Rosman, Abraham, and Paula Rubel

1971 Feasting with Mine Enemy. Rank and Exchange Among Northwest Coast Societies. New York: Columbia University Press.

1972 The Potlatch: A Structural Analysis. American Anthropologist 74:658-671.

Seguin, Margaret

1984 Lest There Be No Salmon: Symbols in Traditional Tsimshian Potlatch. In The Tsimshian. Images of the Past: View for the Present. Margaret Seguin, ed. pp. 110-133. Vancouver: University of British Columbia Press.

1985 Interpretive Contexts for Traditional and Current Coast Tsimshian Feasts. National Museum of Man Mercury Series. Canadian Ethnology Service Paper No. 98.

Shotridge, Louis

1917 My Northland Revisited. Museum Journal 8:105-115.

Snyder, Sally

1975 Quest for the Sacred in Northern Puget Sound: An Interpretation. Ethnology 14:149-161.

Stearns, Mary Lee

1977 The Reorganization of Ceremonial Relations in Haida Society. Arctic Anthropology 14(1):54-63.

Suttles, Wayne

1960 Affinal Ties, Subsistence, and Prestige Among the Coast Salish. American Anthropologist 62:296-305.

1984 Review of Feasting with Cannibals: An Essay of Kwakiutl Cosmology, by Stanley D. Walens. American Indian Quarterly 8(2):138-139.

Swanton, John R.

1908 Social Conditions, Beliefs, and Linguistic Relationship of the Tlingit Indians. In The 26th Annual Report of the Bureau of American Ethnology. pp. 391-486. Washington DC: U.S. Government Printing Office.

1909 Tlingit Myths and Texts. Bureau of American Ethnology Bulletin 39. Washington, DC: U.S. Government Printing Office.

Tollefson, Kenneth D.

1976 The Cultural Foundation of Political Revitalization Among the Tlingit. Ph.D. dissertation. Anthropology Department, University of Washington.

Turner, Victor

1967 The Forest of Symbols. Ithaca, NY: Cornell University Press.

Van Gennep, Arnold

1960 The Rites of Passage. M. B. Vizedom and G. L. Caffee, transl.; S. T. Kimball, introduction. Chicago: University of Chicago Press.

Vaughan, James Daniel

1975 Haida Potlatch and Society: Testing a Structural Analysis. Paper presented at the Northwest Coast Studies Conference, Simon Frazer University, Burnaby, Canada.

1985 Tsimshian Potlatch and Society: Examining a Structural Analysis. In The Tsimshian and Their Neighbors of the North Pacific Coast. Jay Miller and Carol M. Eastman, eds. pp. 58-68. Seattle: University of Washington Press.

Veniaminov, Ivan

1886 Zapiski o koloshakh (Notes on the Tlingit). In Tvorenira lcollected works| of Ivan Veniaminov. Vol. 3. Ivan Barsukov, ed. pp. 573-658. Moscow: Synodal Press.

Walens, Stanley

1981 Feasting with Cannibals. An Essay in Kwakiutl Cosmology. Princeton, NJ: Princeton University Press.

1982 The Weight of My Name is a Mountain of Blankets: Potlatch Ceremonies. In Celebration. Studies in Festivity and Ritual. Victor Turner, ed. pp. 178-189. Washington, DC: Smithsonian Institution Press.

Wallis, W.

1918 Ethical Aspects of Tlingit Culture. American Journal of Psychology 29:66-80.

Weiner, Annette B.

1976 Women of Value, Men of Renown: New Perspectives on Trobriand Exchange. Austin: University of Texas Press.

Wike, Joyce

1952 The Role of the Dead in Northwest Coast Culture. In Indian Tribes of Aboriginal America. Selected Papers of the 29th International Congress of Americanists. Vol. 3. Sol Tax, ed. pp. 97-103. Chicago: University of Chicago Press.

Worl, Rosita

1984 Spiritual Food for the Dead. Tlingit Potlatch Bowls. Alaska Native News (May/June):43. 